\title{
HUBUNGAN PENGETAHUAN IBU NIFAS DENGAN KEBIASAAN YANG MERUGIKAN KESEHATAN IBU NIFAS SEPERTI NYANDA DAN PANTANG MAKANAN SAMPAI DENGAN 6 MINGGU POST PARTUM
}

*Ninik Wahyuni, *Darti Rumiatun

\begin{abstract}
Abtraks
Pengetahuan merupakan hasil dari tahu, dan ini terjadi setelah orangmelakukan penginderaan terhadap suatu objek tertentu. Penginderaan terjadimelalui pancaindera manusia, yakni indera penglihatan, pendengaran,penciuman, rasa dan raba. Sebagian besar pengetahuan manusia diperolehmelalui mata dan telinga (Notoatmodjo, 2007)

Penelitian ini bertujuan untuk Untuk mengetahui Hubungan Pengetahuan ibu tentang asuhan masa nifas terhadap kebiasaan yang merugikan kesehatan seperti nyanda dan pantang makanan.Rancangan Penelitian secara umum mencakup dari identifikasi masalah sehingga tehnik survey analisis akan dilakukan dengan desain cross sectional. Populasi dan sampel penelitian dilakukan pada seluruh ibu nifas sampai dengan 6 mingu post partum yang berada didesa Sukamanah.Dengan demikian dalam penelitian ini yang diambil total populasi.Penelitian ini meliputi variable dependen mengenai pengetahuan ibu nifas dan variable independen kebiasaan yang merugikan kesehatan. Dari hasil penelitian yang sudah dilakukan bahwa pengetahuan dengan kebiasaan yang merugikan kesehatan tidak ada hubungan ynag bermakna yaitu dengan adanya bahwa Asymp Sig-nya adalah 0.209 yang berarti lebih besar dari 0.05, maka Ho diterima.
\end{abstract}

Kata kunci : nyanda,pantang makanan

*Poltekkes Kemenkes Banten 


\section{Pendahuluan}

Pengetahuan merupakan faktor yang san gat penting dalam membentuk tindakan seseorang, sehingga kurangnya pengetahuan tentang tanda bahaya pada masa

kehamilan dapat mempengaruhi seseora ng untuk mempunyai perhatian terhadap keselamatan ibu dan bayi. Jadi pengetahuan ibu tentang tanda bahaya kehamilan merupakan salah satu faktor $p$ enting yang mendukung dalam menurunkan tingginya $\mathrm{AKI}$ dan $\mathrm{AKB}$ di Indonesia (Notoatmojo, 2007). Di Indonesia upaya penurunan AKI haru s difokuskan pada penyebab langsung kematian ibu, yang terjadi $90 \%$ pada saat persalinan, segera setelah persalinan yaitu perdarahan 28\%, Eklam si $24 \%$, Infeksi $11 \%$, Infeksi pueperium8 $\%$, Partus Macet 5\%, abortus 5\%, Trauma Obstetric 5\%, Emboli 3\%, dan lain lain 11\% . (Kementrian Kesehatan Republik Indonesia2011) Masa nifas adalah masa setelah melahirkan hingga pulihnya Rahim dan organ kewanitaan yang umumnya diiringi dengan keluarnya darah nifas, berlangsung selama kurang lebih enam minggu. Pada masa nifas ini ibu akan mendapati beberapa perubahan pada tubuh maupun emosi.
Setelah melahirkan Rahim akan berkontraksi untuk merapatkan dinding Rahim sehingga tidak terjadi perdarahan,kontraksi inilah yang menimbulkan rasa mula spada perut ibu.Ada juga jalan lahir yaitu serviks,vulva dan vagina yang akan mengalami penekanan serta peregangan yang sangat besar selama proses sehingga menyebabkan mengendurnya organ ini bahkan robekan yang memerlukan penjahitan.Darah nifas hingga hari kedua terdiri dari darah segar bercampur sisa ketuban hingga keluar cairan bening diakhir masa nifas.Darah nifas yang berbau sangat amis atau busuk dapat menjadi salah satu petunjuk adanya infeksi dalam Rahim.Oleh karena itu Perawatan ibu nifas merupakan salah satu faktor yang amat perlu diperhatikan untuk mencegah terjadinya komplikasi yang sering terjadi selama masa nifas,

Fakta di berbagai kalangan masyarakat di Indonesia, masih banyak ibu-ibu yang menganggap masa nifas masa yang tidak perlu mendapatkan perhatian khusus karena masa itu sebagai hal yang biasa, alamiah dan kodrati. Mereka merasa tidak perlu memeriksakan dirinya secara rutin ke bidan ataupun dokter. Masih banyaknya 
ibu-ibu yang kurang menyadari pentingnya pemeriksaan masa nifas ke bidan menyebabkan tidak terdeteksinya faktor-faktor resiko tinggi yang mungkin dialami oleh mereka.

Di Indonesia yang termasuk negara heterogen terdiri dari macammacam etnik, macam-macam suku, termasuk macam-macam budaya yang dilestarikan ditempatnya masing-masing, suatu budaya pasti ada yang positif dan ada yang negatif. Kita tidak bisa menghindari budaya tersebut karena kita hidup dalam masyarakat yang berbeda pemikiran antara individu satu dengan yang lainnya untuk menjaga keharmonisan bermasyarakat kita tidak boleh menghindari bahkan menghujat budaya yang berkembang itu. Begitu banyak praktik pantangan - pantangan yang masih dianut dimasyarakat yang merugikan kesehatan. Hal ini kemungkinan disebabkan oleh rendahnya tingkat pendidikan dan kurangnya informasi serta adat istiadat yang dapat merugikan kesehatan khususnya ibu nifas. Mitos atau disebut juga kepercayaan banyak berkembang dikalangan masyarakat kita. Mitos sekitar ibu nifas yang berkembang di masyarakat ada yang merugikan walaupun ada juga yang tidak berdampak apa-apa.

Walaupun pada masyarakat tradisional pemberian ASI bukan merupakan permasalahan yang besar karena pada umumnya ibu memberikan bayinya ASI, namun yang menjadi permasalahan adalah pola pemberian ASI yang tidak sesuai dengan konsep medis sehingga menimbulkan dampak negatif pada kesehatan dan pertumbuhan bayi. Disamping pola pemberian yang salah, kualitas ASI juga kurang. Hal ini disebabkan banyaknya pantangan terhadap makanan yang dikonsumsi si ibu baik pada saat hamil maupun sesudah melahirkan. Sebagai contoh, pada masyarakat Kerinci ibu yang sedang menyusui pantang untuk mengkonsumsi bayam, ikan laut atau sayur nangka. Di beberapa daerah ada yang memantangkan ibu yang menyusui untuk memakan telur.Didaerah pedesaan masih banyak ibu hamil yang mempercayai dukun beranak untuk menolong persalinan dirumah.data survey kesehatan rumah tangga tahun 1992 menunjukkan bahwa 65\% persalinan ditolong oleh dukun beranak.Beberapa penelitian yang pernah dilakukan mengungkapkan bahwa terdapat praktek persalinan oleh 
dukun yang membahayakan si ibu.Penelitian Iskandar dkk menunjukkan beberapa dan praktek yang membawa resiko infeksi salah satunya nyanda (setelah persalinan ,ibu duduk dengan posisi bersandar dan kaki diluruskan kedepan selama berjam -jam yang dapat menyebabkan perdarahan dan pembengkakan)

(Midwifebieehafshawaty, 2013 ).

Selain kebiasaan nyanda yang membahayakan ada juga pantangan makanan ini merupakan gejala yang hampir universal berkaitan dengan konsepsi "panas-dingin" yang dapat mempengaruhi keseimbangan unsurunsur dalam tubuh manusia -tanah, udara, api dan air. Apabila unsur-unsur di dalam tubuh terlalu panas atau terlau dingin maka akan menimbulkan penyakit. Untuk mengembalikan keseimbangan unsur-unsur tersebut maka seseorang harus mengkonsumsi makanan atau menjalani pengobatan yang bersifat lebih "dingin" atau sebaliknya. Pada, beberapa suku bangsa, ibu yang sedang menyusui kondisi tubuhnya dipandang dalam keadaan "dingin" sehingga ia harus memakan makanan yang "panas" dan menghindari makanan yang "dingin". Hal sebaliknya harus dilakukan oleh ibu yang sedang hamil (Reddy, 1990).

Pelayanan Ibu Nifas di kabupaten pandeglang yang telah dilakukan sebagai salah satu usaha untuk menekan angka kematian ibu ,seperti setelah melahirkan dan masih banyak lagi hal yang merugikan kesehatan sehingga berdampak ibu dan penurunan angka kesakitan merupakan tantangan yang harus diupayakan, adapun hasil cakupan pelayanan nifas (Kf Lengkap) tahun 2010 sebesar $81,95 \%$ dari rencana target $90 \%$, sehingga capaian pelayanan ibu nifas (Kf 1) sebesar 91,05\%.(profil kabupaen pandeglang, 2010)

Masih adanyan pantanganpantangan atau anjuran masih diberlakukan juga pada masa pasca persalinan. Pantangan ataupun anjuraan ini biasanya berkaitan dengan proses pemulihan kondisi fisik misalnya, ada makanan tertentu yang sebaiknya dikonsumsi untuk memperbanyak produksi ASI; ada pula makanan tertentu yang dilarang karena dianggap dapat mempengaruhi kesehatan bayi

Bidan salah satu tugas dan tanggung jawabnya adalah memberikan asuhan pada klien dalam masa nifas dengan melibatkan 
klien/keluarga.memiliki kewajiban memberikan asuhan kepada ibu dan anak yang meminta pertolongan kepadanya.Oleh karena itu kegiatan Bidan sangat erat dengan keluarga. Salah satu pelayan yang harus diberikan adalah melakukan asuhan kepada ibu nifas.Dengan asuhan nifas yang tepat maka ibu nifas dapat mengubah pola Pikir yang kuno itu menjadi modern dengan pembaharuan kesehatan tentunya kesehatan Ibu dan Anak. .Sehingga penulis tertarik untuk melakukan penelitian dengan judul Hubungan Pengetahuan ibu tentang asuhan masa nifas terhadap kebiasaan yang merugikan kesehatan seperti nyanda dan pantang makanan didesa Sukamanah Kecamatan Kaduhejo Kabupaten Pandeglang Propinsi Banten Periode Mei sampai dengan Nopember 2015.

\section{Metode Penelitian}

Rancangan Penelitian secara umum mencakup dari identifikasi masalah sehingga tehnik survey analisis akan dilakukan dengan desain cross sectional. Waktu penelitian dilakukan dari bulan Mei sampai dengan nopember 2015 di desa Sukamanah Kecamatan Kaduhejo Kabupaten Pandeglang. Populasi dan sampel penelitian dilakukan pada seluruh ibu nifas sampai dengan 6 mingu post partum yang berada didesa Sukamanah. Dengan demikian dalam penelitian ini yang diambil total populasi dengan kriteria inklusi ibu nifas dengan persalinan spontan atau normal,serta domisili didesa Sukamanah dan berada dirumah.

\section{Hasil}

Analisis Univariat

Tabel 1

Distribusi frekuensi ibu nifas berdasarkan pengetahuan tentang masa nifas

\begin{tabular}{|l|l|l|}
\hline \multicolumn{1}{|c|}{ Pengetahuan } & Jumlah & presentasi \\
\hline Rendah & 28 & 77.8 \\
\hline Tinggi & 8 & 22.2 \\
\hline & 36 & $100 \%$ \\
\hline
\end{tabular}

Berdasarkan tabel diatas menunjukkan bahwa pengetahuan ibu nifas tentang asuhan masa nifas sebagian besar rendah $(77,8 \%)$.

Tabel 2

Distribusi Ibu Nifas Berdasarkan Kebiasaan Yang Dilakukan

\begin{tabular}{lll}
\hline \multicolumn{1}{c}{ Kebiasaan } & Frekuensi & Persentasi \\
\hline Merugikan & 25 & 69,4 \\
Baik & 11 & 30,6 \\
\hline & 36 & $100 \%$ \\
\hline \multicolumn{2}{c}{ Berdasarkan } & tabel diatas
\end{tabular}
menunjukkan bahwa ibu nifas sebagian besar melakukan kebiasaan merugikan $(69,4 \%)$ 
Tabel 3

Distribusi Ibu Nifas Berdasarkan

Hubugan Pengetahuan Dengan

Kebiasaan

\begin{tabular}{lccc}
\hline \multirow{2}{*}{ Kebiasaan } & \multicolumn{2}{c}{ Pengetahuan } & P value \\
& Rendah & Tinggi & \\
\hline Merugikan & 18 & 7 & \\
& $(64,3 \%)$ & $(87,5)$ & 0,209 \\
Baik & 10 & 1 & \\
& $(35,7 \%)$ & $(12,5)$ & \\
\hline \multicolumn{1}{c}{ Total } & 28 & 25 & \\
& $(100 \%)$ & $(100 \%)$ & \\
\hline
\end{tabular}

Dari tabel diatas dapat terlihat bahwa ibu dengan hasil pengatahuan rendah melakukan kebiasaan merugikan 64,3\% dibandingkan dengan Pengetahuan Rendah yang melakukan kebiasaan baik yaitu $(35,7 \%)$. Dengan menggunakan Uji Chi Square pada alpha 0,05 diperoleh nilai 0,209 ( $\mathrm{p}>0,05)$, yang berarti secara statistic, maka Ho diterima.Yang artinya tidak ada hubungan antara tingkat pengetahuan dengan kebiasaan yang merugikan kesehatan.

\section{Pembahasan}

Dari hasil penelitian yang sudah dilakukan bahwa pengetahuan dengan kebiasaan yang merugikan kesehatan tidak ada hubungan yang bermakna dimasyarakat,hal ini sesuai dengan teori (Notoatmojo 2010) bahwa kebiasaan dan tradisi yang dilakukan orang-orang tanpa melalui penalaran apakah yang dilakukan baik atau buruk.Dengan demikian seseorang akan bertambah pengetahuannya walaupun tidak melakukan.Status ekonomi seseorang juga akan menentukan tersedianya suatu fasilitas yang diperlukan untuk kegiatan tertentu,sehingga status social ekonomi ini akan mempengaruhi pengetahuan seseorang.Sosial budaya mempunyai pengaruh pada pengatahuan seseorang.Seseorang memperoleh suatu kebudayaan dalam hubungannya dengan orang lain,karena hubungan ini seseorang menggalami suatu proses belajar dan memperoleh suatu pengetahuan.Sosial budaya mempunyai pengaruh pada pengetahuan seseorang mengalami suatu proses belajar dan memperoleh suatu pengetahuan ,menurut pendapat peneliti selain social budaya pengalaman bisa juga dijadikan pengetahuan,pengalaman merupakan guru yang terbaik.Pepatah tersebut dapat diartikan bahwa pengalaman merupakan guru yang terbaik.Pepatah tersebut dapat diartikan bahwa pengalaman merupakan sumber pengetahuan atau pengalamanitu suatu cara memperoleh kebenaran pengetahuan.Oleh sebab itu ,pengalaman pribadi pun dapat digunakan sebagai upaya untuk memperoleh pengatahuan.Hal ini dilakukan dengan cara mengulang kembali pengalaman yang diperoleh dalam memecahkan permasalahan yang dihadapi pada masa 
lalu (Notoatmodjo,1997 dalam Rahmayani,2010).

Untuk kebiasaan yang merugikan kesehatan dalam hal ini nyanda dan pantang makan itu merupakan hal yang membahayakanbagi ibu nifas ,seperti pada masa nifas dilarang makan telur,daging,udang,ikan laut dan lele,keong,daun lembayung,buah pare,nenas,gula merah dan makanan yang berminyak adalah dapat merugikan karena pada masa nifas ,ibu membutuhkan makanan yang bergizi seimbang agar ibu dan bayi menjadi sehat dan dampak positif dari larangan ini tidak ada.

Penelitian (Iskandar dkk 1996 dalam Afshawati,2013) menunjukkan beberapa tindakan/praktek yang memawa resiko infeksi seperti "ngolesi" (membasahi Vagina dengan minyak kelapa untuk memperlancar persalinan)"Kodok" (memasukkan tangan ke dalam vagina dan uterus untuk mengeluarkan plasenta) atau "nyanda" (setelah persalinan ,ibu duduk dengan posisi bersandar dan kaki diluruskan ke depan selama berjam-jam yang dapat menyebabkan perdarahan dan pembengkakan).

\section{Simpulan}

Bahwa simpulan dari hasil yang didapat adalah ibu nifas yang menjadi sample adalah seluruh populasi didesa Sukamanah sebanyak 36 ibu nifas.

1.Dengan menggunakan Uji Chi Square ini akan mengamati secara lebih detail tentang ada dan tidaknya hubungan antara Pengetahuan Tinggi dan Rendah dengan melakukan kebiasaan baik dan merugikan,dapat dilihat dari tabel data tersebut tersebut terlihat bahwa Asymp Sig-nya adalah 0.209 yang berarti lebih besar dari 0.05, maka H0 diterima.Sehingga tidak ada hubungan yang bermakna antara antara hasil pengetahuan ibu tinggi dengan hasil pengetahuan rendah dengan kebiasaan yang merugikan kesehatan.Frequensi pengetahuan ibu nifas yang tinggi dan rendah menunjukkan bahwa ibu nifas dengan hasil pengetahuan rendah sebanyak 28 orang $(77,8 \%)$ dan dengan hasil pengetahuan tinggi sebanyak 8 orang $(22,2 \%)$ dikarenakan pengaruh sosial budaya dan pengalaman.

2. Kebiasaan yang merugikan kesehatan seperti nyanda dan pantang makan tidak ada perubahan yang berdampak positif.

\section{Daftar Pustaka}

Alimut Azis, 2007 Metode Penelitian Kebidanan dan Tehnis Analisis Data,Jakarta,

Asrinah dkk, 2010 Asuhan Kebidanan Masa Persalinan, Yogyakarta ,

Dinkes Propinsi Banten, 2014. Profil Kesehatan propinsi Banten, 
Dinkes kabupaten Pandeglang , 2010 .

Profil Kesehata Kabupaten

Pandeglang Tahun 2009.

Jannah Nurul 2011,Asuhan Kebidanan Ibu Nifas,Jogjakarta,

Mochtar,Sinopsis Obstetri

.EGC.Jakarta,200

Notoatmojo,Soekidjo, 2012, Metodologi

Penelitian Kesehatan, Rineka cipta.Jakarta

Prawiriharjo,Sarwono, $2008 \quad$ Ilmu Kebidanan. yayasan Bina Pustaka SarwonoPrawiroharjo.Jakarta,

Saifudin.2006. Buku Acuan Nasional Pelayanan Kesehatan Maternal dan neonatal.Yayasan Bina Pustaka sarwono Prawiroharjo.Jakarta,2006

Saryono, 2011 Metodolgi Penelitian Kesehatan,Jogjakarta,

Varney Helen, 2003 Buku saku Bidan,Jakarta,

Wibowo, Adik 1993 Kesehatan Ibu di Indonesia: Status "Praesens" dan Masalah yang dihadapi di lapangan. Makalah yang dibawakan pada Seminar " Wanita dan Kesehatan", Pusat Kaajian Wanita FISIP UI, di Jakarta 
